\title{
Papillary, Follicular, Hurthle Cell, Poorly Differentiated, and Anaplastic Thyroid Carcinoma Clinical Distant Metastasis TNM Finding v8
}

National Cancer Institute

\section{Source}

National Cancer Institute. Papillary, Follicular, Hurthle Cell, Poorly Differentiated, and Anaplastic Thyroid Carcinoma Clinical Distant Metastasis TNM Finding v8. NCI Thesaurus. Code C140899.

A clinical finding about one or more characteristics of papillary, follicular, Hurthle cell, poorly differentiated, and anaplastic thyroid carcinoma, following the rules of the TNM AJCC v8 classification system as they pertain to distant metastases. 